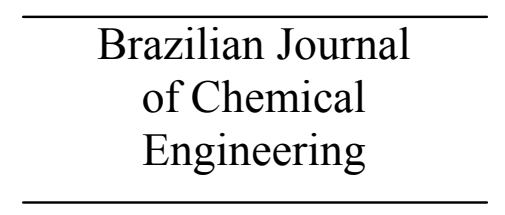

ISSN 0104-6632

Printed in Brazil

www.abeq.org.br/bjche

Vol. 27, No. 01, pp. 15 - 29, January - March, 2010

\title{
SEED LIPASES: SOURCES, APPLICATIONS AND PROPERTIES - A REVIEW
}

\author{
M. Barros ${ }^{1 *}$, L. F. Fleuri ${ }^{2}$ and G. A. Macedo ${ }^{1}$ \\ ${ }^{1}$ Food Science Department, School of Food Engineering, University of Campinas (UNICAMP), \\ Phone: + (55) (19) 3521-2175, Fax: +(55) (19) 35212153, \\ P.O. Box: 6121, 3083-862, Campinas - SP, Brazil. \\ E-mail:marcio32@fea.unicamp.br \\ E-mail: marciodebarros@hotmail.com \\ ${ }^{2}$ Chemistry and Biochemistry Department, Institute of Biosciences, \\ São Paulo State University (UNESP), P.O. Box 510, \\ 18618-000, Botucatu - SP, Brazil.
}

(Submitted: September 25, 2009 ; Revised: December 7, 2009 ; Accepted: January 18, 2010)

\begin{abstract}
This paper provides an overview regarding the main aspects of seed lipases, such as the reactions catalyzed, physiological functions, specificities, sources and applications. Lipases are ubiquitous in nature and are produced by several plants, animals and microorganisms. These enzymes exhibit several very interesting features, such as low cost and easy purification, which make their commercial exploitation as industrial enzymes a potentially attractive alternative. The applications of lipases in food, detergents, oils and fats, medicines and fine chemistry, effluent treatment, biodiesel production and in the cellulose pulp industry, as well as the main sources of oilseed and cereal seed lipases, are reviewed.

Keywords: Vegetable Lipases; Reactions; Sources; Application.
\end{abstract}

\section{INTRODUCTION}

Lipase enzymes have become more and more prominent on the enzyme biotechnology scenario due to their versatility for hydrolysis and synthesis, their catalytic reactions often being chemo-selective, region-selective or enantio-selective. Lipases are used in many sectors such as the food, pharmaceutical, fine chemical, oil chemical, biodiesel and industrial detergent industries (Freire and Castilho 2008, Alonso et al. 2005). The participation of lipases in the worldwide enzyme industry market has grown significantly and it is believed that, in the future, they will acquire importance comparable to that of the peptidases, which currently represent 25 to $40 \%$ of industrial enzyme sales (Hasan et al. 2006).
Lipases act, by definition, at the organic-aqueous interface, catalyzing the hydrolysis of estercarboxylate bonds and releasing fatty acids and organic alcohols (Pereira et al., 2003; Leal et al. 2002; Kamimura et al., 1999; Merçon et al. 1997). However, as Pottevin showed for the first time in 1906, in water-restricted environments, the reverse reaction (esterification) or even various transesterification reactions can occur (Freire and Castilho 2008, Castro et al. 2000). The term transesterification refers to the exchange of groups between an ester and an acid (acidolysis), between an ester and an alcohol (alcoholysis) or between two esters (interesterification). Their ability to catalyze these reactions with great efficiency, stability and versatility makes these enzymes highly attractive from a commercial point of view (Figure 1).

*To whom correspondence should be addressed 

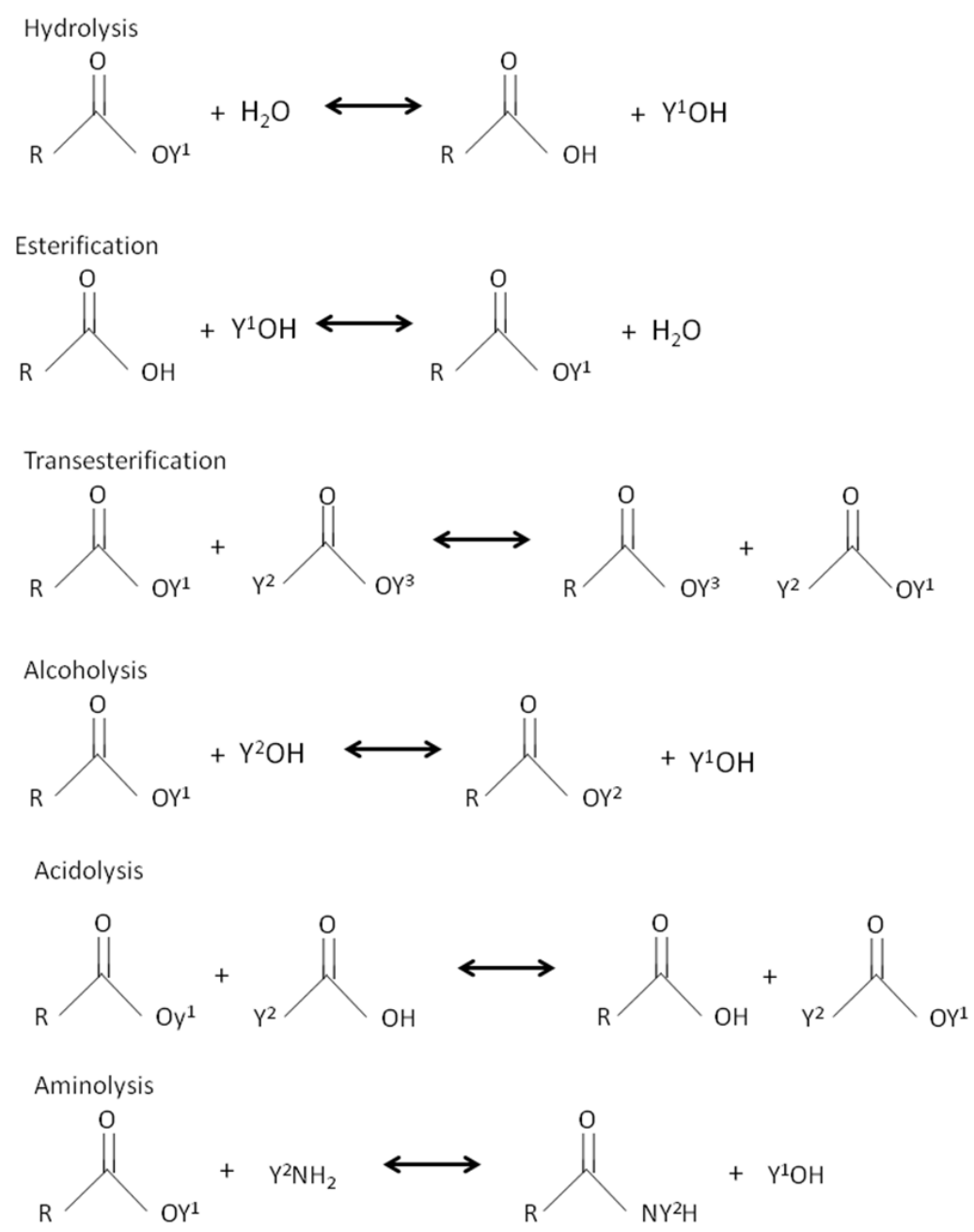

Figure 1: Reactions catalyzed by lipases. (Paques and Macedo, 2006)

According to Villeneuve (2003), Macrae and Hammond (1985) and Sonnet (1988), lipase specificities can be divided into three main groups as follows:

1. Substrate specificity: the natural substrates are glycerol esters. Not only are these enzymes able to catalyze the hydrolysis of triacylglycerols (TAGs), but also di- and monoacylglycerols and even phospholipids, in the case of phospholipases.

2. Regioselective - subdivided into:

I. Non-specific lipases: catalyze the complete hydrolysis of triacylglycerols into fatty acids and glycerol in a random way, mono- and diacylglycerols being intermediate products (Figure 2).

II. Specific 1.3 lipases: only hydrolyse triacylglycerols at the $\mathrm{C} 1$ and $\mathrm{C} 3$ glycerol bonds, producing fatty acids, 2-monoacylglycerols and 1.2- or 2.3-diacylglycerols, the latter two being chemically unstable, promoting migration of the acyl group producing 1.3-diacylglycerol and 1- or 3monoacylglycerols (Figure 2).

III.Specific or selective type fatty acid: lipases can be specific for a particular type of fatty acid or, more frequently, for a specific group of fatty acids. They hydrolyze fatty acid esters located at any triacylglycerol position.

3. Enantioselective: the ability to discriminate enantiomers in a racemic mixture. An example of this is the R-isomer of sparteine 9, which tastes sweet, whereas the S-isomer tastes bitter. The enantio specificities of lipases can vary according to the substrate and this variation can be connected to the chemical nature of the ester (Castro and Anderson, 1995). 

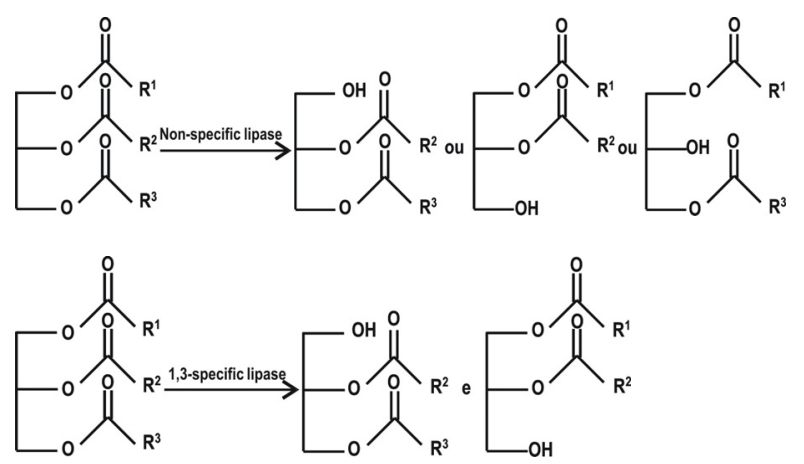

Figure 2: Reactions catalyzed by non-specific and 1,3 specific lipases (adapted from Paques and Macedo 2006).

Lipases can be of animal (pancreatic, hepatic and gastric), microbial (bacterial, fungal and yeast) or vegetable origin, with variations in their catalytic properties (Mukherjee and Hills, 1994). Nevertheless, despite the extensive range of microbial lipases, the use of these enzymes on an industrial scale is still restricted due to high production costs, favoring the search for other sources of these enzymes (Parques and Macedo, 2006).

Recently, seed lipases have been the focus of much attention as biocatalysts. In some cases, these enzymes present advantages over animal and microbial lipases due to some quite interesting features such as specificity, low cost, availability and ease of purification, representing a great alternative for potential commercial exploitation as industrial enzymes (Polizeli et al., 2008; Parques and Macedo, 2006; Enujagha et al., 2004; Villeneuve, 2003; Hellyer, et al. 1999).

The modification of fats and oils by transesterification, for instance, can be performed by both chemical and enzymatic catalysis. The industrial transesterification process is currently performed by chemical means, using high temperatures and alkaline metals as the reaction catalyst (Ribeiro et al., 2009). In the enzymatic process, lipases can be used as biocatalysts to promote the exchange of triacylglycerols, showing greater efficiency and leaving no residues (Xu, 2000). However, several studies have indicated that such processes are very expensive due to the high cost of purifying the microbial enzymes (de Castro et al., 2004; Noor et al., 2003). Seed lipases present certain advantages since they do not necessarily have to be purified in order to perform this and other processes (Caro et al., 2000). A partially purified raw extract of Nigella sativa L. was used by Tuter et al. (2003) as a lipase source for enriching borage oil with gamma-linolenic fatty acid, obtaining 34.6\% incorporation.
Thus, this review will cover studies involving seed lipases, including their possible industrial applications according to their individual features.

\section{Seed Lipases}

In order to study seed lipases, one must understand their physiological functions as well as their activity in agricultural products during storage. In germinated oilseeds, mobilization of the stored fatty acid is essential to supply energy and carbon for embryonic growth. Lipolytic enzymes catalyze the first step of lipid mobilization, with the possibility of subsequently being controlled during and after the germination period (Quettier and Eastmond, 2009; Borgston e Brockman, 1984).

Basically, oilseeds are composed of two fundamental parts: the husk or tegument and the kernel. The tegument or husk is the external layer of the seed covering the kernel, the latter being considered the main part of the seed. The kernel has two parts: the embryo or germ that will form the new plant when the seed germinates; and the albumin or endosperm, which stores the reserve nutrients that will feed the plant in the first stages of development.

Grains generally contain proteins and, depending on the plant species, starch or triacylglycerols as energy reserve sources. In the mobilization of these three major nutrient reserves during germination, they are hydrolyzed specifically by proteases, amylases and lipases, respectively. Many researchers have investigated seed lipase at the height of its activity during grain germination (Hellyer et al., 1999; Parques and Macedo, 2006).

From $20 \%$ to $50 \%$ of the dry weight of oilseeds is basically stored triacylglycerols. During the germination period, the triacylglycerols stored in "oil bodies" or "oleosomes" are quickly used up in the production of energy for the synthesis of the sugars, amino acids (mainly asparagine, aspartate, glutamine and glutamate) and carbon chains required for embryonic growth (Quttier and Eastmond, 2009; Ejedegba et al., 2007; Borek, et al., 2006; Huang et al. 1988).

Figure 3 shows the hydrolysis of seed triacylglycerol to free fatty acids and glycerol by the action of one or more lipases. The glycerol formed is phosphorylated and subjected to glycogenesis after its conversion to dihydroxyacetone phosphate (DHAP) (Quettier et al. 2008). The free fatty acids are transported into the peroxisome, where they are activated into acytil-COA and initiate $\beta$-oxidation. The acetyl-COA produced by $\beta$-oxidation enters the glyoxylate cycle and subsequently takes part in glycogenesis to produce the sugar required by the embryo as an energy source during germination (Quttier and Eastmond, 2009). 


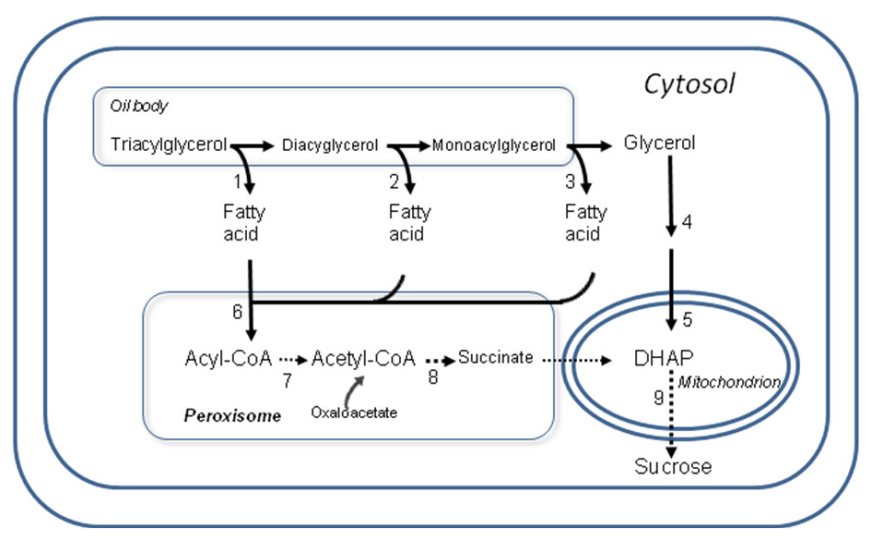

Figure 3: Triacylglycerols (TAG) stored in the lipid bodies are hydrolyzed to fatty acids (FA) and glycerol (Gly) by the sequential action of one or more lipases $(1,2,3)$. Gly is converted to dihydroxyacetone phosphate (DHAP) by the action of Gly kinase (4) and Gly-3-phosphate dehydrogenase (5). The FAs are transported into the peroxisome, where they are activated into acyl-CoAs (6) and enter the $B$-oxidation spiral (7). Acetyl-CoA condenses with oxaloacetate (OAA) to form succinate (8). Succinate and DHAP are converted to sugars such as sucrose by gluconeogenesis (9) (Adapted from Quttier and Eastmond, 2009).

In most cases, lipolytic activity is not observed in the non-germinated seeds, but only in postgerminated seeds (Hassanien and Mukherjee, 1986; Villeneuve, 2003). Also, depending on the plant, the lipases may be located in the lipid bodies or in other sub-cellular compartments. In seeds in which the lipase is found in sub-cellular compartments, the enzyme may be free or associated with organelles. In seeds in which the lipase is in sub-cellular compartments that are not lipid bodies, the enzymes will have contact with the lipid body membranes during catalysis (Eastmond, 2004).

\section{Specificity of Seed Lipases}

With some exceptions, oilseed lipases are generally more active with triacylglycerols containing short chain fatty acids. Commonly used substrates include commercially produced plant oils with unknown purity and non-specific polluting agents, triacylglycerols with short chain fatty acids such as acetic and butyric acids, saturated and non-saturated acylglycerols and fluorescent substrates with molecular structures composed of monoesters (Borgston and Borckman, 1984; Enujiagha et al., 2004).

According to Hellyer et al. (1999), seed lipases show selectivity for the dominant fatty acids in the seed. For example, castor bean lipases show selectivity for triricinolein; palm tree lipase for tricaproin or trilaurein; elm lipase for tricaproin and Vermonia sp. lipase for trivernolein. Other seed lipases can quickly hydrolyze a great variety of fatty acids, such as canola and pinus seed lipases. Canola seed lipase usually presents activity with most lipids, but discriminates fatty acids with cis-4 or cis-6 double-bonds.

Tables 1 and 2 show the hydrolysis of several triacylglycerols and of synthetic 4-methylumbelliphenyl substrates, respectively, by seed lipases.

Table 1: Hydrolysis of several triacylglycerols by lipases from various seed sources

\begin{tabular}{|c|c|c|c|c|c|c|c|c|c|}
\hline \multicolumn{10}{|c|}{ Relative activity (\%) } \\
\hline \multicolumn{2}{|c|}{ Triacylglycerols } & Castor & Corn & Rapeseed & $\begin{array}{c}\text { Rapeseed } \\
\text { (erucid acid }\end{array}$ & EIm & Mustard & Palm & Pinus \\
\hline Tricaproin & C10:0 & 43 & 27 & 89 & - & 100 & - & 100 & 74 \\
\hline Trilaurein & $\mathrm{C} 12: 0$ & 60 & 0 & 31 & - & 4 & - & 60 & 78 \\
\hline Trimyristin & $\mathrm{C} 14: 0$ & 26 & 0 & 92 & - & 3 & - & 15 & 89 \\
\hline Tripalmitin & $\mathrm{C} 16: 0$ & 46 & 0 & 27 & 51 & 0 & 39 & 35 & 85 \\
\hline Tristearin & $\mathrm{C} 18: 0$ & 62 & 0 & 36 & 89 & 0 & 40 & - & 103 \\
\hline Triolein & $\mathrm{C} 18: 1$ & 55 & 38 & 44 & 138 & 4 & 96 & - & 96 \\
\hline Trilinolein & $\mathrm{C} 18: 2$ & 57 & 100 & 89 & 116 & 6 & 89 & - & 100 \\
\hline Triricinolenin & $\mathrm{C} 18: 3$ & 100 & 0 & 83 & - & 0 & - & - & 114 \\
\hline Tribehenin & $\mathrm{C} 22: 0$ & - & 0 & 16 & - & 0 & - & - & 83 \\
\hline Trierucin & $\mathrm{C} 22: 1$ & 36 & 45 & 100 & 100 & 0 & 100 & - & - \\
\hline Triarachidin & & - & - & - & - & - & - & - & 60 \\
\hline
\end{tabular}


Table 1 shows that the seed lipases evaluated had greater activity for the triacylglycerols containing the fatty acids found in higher percentages in the nutrient reserve tissue of that seed. Such affinity is of great physiological significance for the seed (Quettier and Eastmond, 2009; Hellyer et al., 1999; Hammer and Murphy, 1993).

Corn lipase, for instance, presented greater activity with the triacylglycerols containing oleic and linolenic acids, which are the main constituents of corn oil. Similarly, elm lipase showed a high level of specificity and activity for tricaprin, and less than $10 \%$ of activity with the other triacylglycerols studied. This specificity level is even greater than that of palm seed lipase for caproic acid, which represents a greater percentage of the storage triacylglycerols of this seed (Lin, 1986; Hammer and Murphy, 1993).

With synthetic substrates, lipases are found to present the same pattern they present with natural substrates (Table 2). Lipases from corn, canola and elm seeds were more active with 4-methylumbelliferyl oleate, whereas the lipase from pinus seed was more active with 4-methyl-umbelliferyl laurate, showing no connection with fatty acid chain size, since it presented high laurate and oleate activities and low stearate activity (Lin, 1986; Hammer and Murphy, 1993).

Table 2: Hydrolysis of synthetic substrates (acyl 4-methyl-umbelliphenyl) by lipases from various sources.

\begin{tabular}{|l|r|r|r|r|}
\hline \multicolumn{5}{|c|}{ Relative Activity (\%) } \\
\hline $\begin{array}{l}\text { Substrate } \\
\text { (4-methyl- } \\
\text { umbelliferyl) }\end{array}$ & Corn & Canola & EIm & Pinus \\
\hline Laureate & 32 & 35 & 169 & 100 \\
Palmitate & 12 & 4 & 29 & 28 \\
Estearin & 5 & 44 & 53 & 6 \\
Oleate & 100 & 100 & 100 & 81 \\
Elaidic & - & - & - & 51 \\
\hline
\end{tabular}

\section{Oilseed Lipases}

Genuine lipases are those that hydrolyze fatty acids bonded to their respective triacylglycerols. In vegetables, they are present in oleaginous seeds (oilseeds) and other cereal seeds. During the germination period of oilseeds, the lipid reserve is rapidly used up in the production of energy for embryonic growth. During this period, lipolytic activity is very high and, depending on the plant species, the lipase may be located in the membrane of the lipid bodies or in other cellular compartments (Borgston and Borckman, 1984).
The following are the most widely studied oilseed grains with respect to lipase extraction and characterization: beans (Enujiugha et al., 2004); sunflower seeds (Sagiroglu and Arabaci, 2005; Sadeghipour and Bhatla, 2003); linseed (Sammour, 2005); peanuts (Huang and Moriau, 1978) and cotton seeds (Rakhimov et al., 1970), although lipases from other oilseed sources are currently being investigated. Some of these studies and the characteristics of the oilseed lipases, such as those from beans, sunflower seeds, canola, Barbados nut, lupin, linseed, coconut, French peanut, almond, laurel and black cumin, are described and discussed in this review.

\section{Bean Lipases}

Bean lipases are well known and characterized. They are generally more active at $\mathrm{pH}$ levels close to neutrality, with an optimum temperature of $30^{\circ} \mathrm{C}$ and specificity for short and medium chain fatty acids.

Enujiugha et al. (2004) studied the lipolytic activity of Africa bean seeds (Pentaclethra macrophylla Benth) and the enzyme showed greater activity with oils containing short chain fatty acids, especially coconut oil. The optimum temperature of the lipase was $30^{\circ} \mathrm{C}$, but at $80^{\circ} \mathrm{C}$ it still showed lipolytic activity, indicating that it is a heat stable enzyme. The optimum $\mathrm{pH}$ was close to neutrality. The authors also observed the effects of different salts on enzymatic activity and found that the presence of $\mathrm{Ca}^{2+}$ salts enhanced the activity at $64 \%$, whereas sodium chloride and mercury chloride inhibited the activity at $36 \%$ and $28.55 \%$, respectively. The addition of EDTA caused inhibition of $28 \%$ of the activity.

French bean lipase was studied by Kermash and Van de Voort (1986), who investigated the effects of $\mathrm{pH}$, calcium concentration and the addition of emulsifying agents. The results showed that the enzyme presented greater activity at $\mathrm{pH} 7.0$ and that the addition of calcium had an inhibitory effect, whereas the addition of the emulsifier Tween-20 resulted in a four-fold increase in enzyme activity. The specificity of the French bean lipase was compared to that of pancreatic lipase using as substrates triacetin, olive oil and French bean oil. The raw French bean lipase showed greater activity than pancreatic lipase in all these substrates, the highest activity being detected with triacetin.

Castor beans contain a lipase with some peculiar characteristics. The enzyme showed optimum activity at a $\mathrm{pH}$ close to 4.5 and was inactivated at $\mathrm{pH}$ values above 6.0 at a temperature of $30^{\circ} \mathrm{C}$. This acid lipase exhibited specificity for short and 
medium chain fatty acids and also for non-saturated ones. In addition, it showed some regioselectivity for fatty acids at the positions $s n-1$ and $s n-2$ (Eastmond, 2004).

Tüter (1998) studied castor bean lipase as a biocatalyst in esterification reactions. The author evaluated parameters such as incubation time, $\mathrm{pH}$, enzyme concentration and the glycerol to fatty acid molar ratio. The best reaction conditions were found to be 4 hours at $\mathrm{pH} 4.0$ with $20 \%$ of enzyme extract and a 5:1 glycerol to fatty acid molar ratio. According to the author, this enzyme shows good prospects for industrial use.

\section{Sunflower Seed Lipases (Heliantus annuus L.)}

The reduction in stored lipids during the germination of sunflower seeds was studied by establishing a correlation with the seed proteins (Sadeghipour and Bhatla, 2003). The results showed that seeds growing in the sunlight showed greater lipolytic activity and a concomitant expressive increase in proteins with molecular weights of 40-50 kDa.

Sagiroglu and Arabaci (2005) studied the physical-chemical properties of purified sunflower seed lipase (Heliantus annuus L). The researchers observed that the monomeric lipase usually presented a molecular weight of $22 \mathrm{kDa}$ and a pI of 8.0, and showed behavior similar to that of a typical lipase, with a $\mathrm{K}_{\mathrm{m}}$ of $1.33 \mathrm{mM}$ and $\mathrm{V}_{\max }$ of $555 \mathrm{U} / \mathrm{mg}$. It showed a preference for triacylglycerols with mono-unsaturated fatty acids, a high temperature of $50^{\circ} \mathrm{C}$ and a high $\mathrm{pH}$ value of 7.5 . Enzyme stability was also evaluated during grain storage, and it was shown that the lipolytic activity was preserved in a temperature range from 35 to $50^{\circ} \mathrm{C}$ with an alkaline $\mathrm{pH}$ value for a period of about four months.

\section{Canola Lipases (Brassica napus L.)}

Sana et al. (2004) evaluated the physicalchemical properties of germinated canola seed lipase (Brassica napus L.) purified by chromatography in a column packed with Sephadex G-50, DEAE and CM-cellulose. Using triolein as the substrate, the highest activity was found at $\mathrm{pH} 7$ with a temperature of $37^{\circ} \mathrm{C}$. In the presence of $\mathrm{Ca}^{2+}$ and $\mathrm{Bi}^{3+}$ ions, the lipolytic activity was found to increase by $165 \%$ and $124 \%$, respectively. $\mathrm{Fe}^{3+}, \mathrm{Fe}^{2+}, \mathrm{Zn}^{2+}$, $\mathrm{Hg}^{2+}$ and $\mathrm{Cu}^{2+}$ ions inhibited the lipolytic activity and $\mathrm{Al}^{3+}$ and $\mathrm{Pb}^{2+}$ ions had no influence on the hydrolysis activity.

Lin et al. (1986) studied the activity of canola lipase in different substrates. The enzyme showed high activity when acting on trierucic, tripalmitate and 4-methyl- umbeliferyl oleate.

Liaquat and Apenten (2000) studied the formation of low molecular weight esters in an organic medium composed of hexane, using enzymes precipitated from different vegetable seeds by ammonium sulphate. Direct esterification of acetic, butyric and caproic acid by ethanol, butanol, isobutanol or (Z)-3-hexen-1-ol was also carried out. Of the grain lipases studied (wheat, linseed, barley and canola), canola seed lipase showed the highest degree of flavor formation, producing (Z)-3-hexen-1yl butyrate and (Z)-3-hexen-1-yl caproate with an efficiency of about $96 \%$.

\section{Barbados Nut Lipases (Jatropha curcas L.)}

Seed lipases from Jatropha curcas L., also known as Barbados nut, were studied by Abigor et al. (2002). The lipase was partially purified using a combination of ammonia sulphate precipitation and ultrafiltration. The enzyme showed high activity in triolein at a high $\mathrm{pH}$ of 7.5 and temperature of $37^{\circ} \mathrm{C}$. The authors observed that the addition of $\mathrm{Fe}^{2+}$ $(15 \mathrm{mM})$ inhibited $90 \%$ of the enzymatic activity, whereas the addition of $\mathrm{Ca}^{2+}$ increased it by $130 \%$ and that of $\mathrm{Mg}^{2+}$ by $30 \%$.

Staubmann et al. (1999) also studied Barbados nut seeds and found two esterases (JEA and JEB) and a lipase (JL). They only observed lipolytic activity in the grain during the germination period, reaching a maximum 4 days after germination. All three enzymes (precipitated by ethanol and purified by gel filtration) presented optimum activity at an alkaline $\mathrm{pH}$ of about 8.0. Using $p$-nitrophenyl butyrate as the substrate, JEA showed a value for $\mathrm{K}_{\mathrm{m}}$ of $0.02 \mathrm{mM}$ and $\mathrm{V}_{\max }$ of $0.26 \mu \mathrm{mol} . \mathrm{mg}^{-1} \cdot \mathrm{min}^{-1}$, and under the same conditions, JEB showed a value for $\mathrm{K}_{\mathrm{m}}$ of $0.07 \mathrm{mM}$ and $\mathrm{V}_{\max }$ of $0.24 \mu \mathrm{mol} . \mathrm{mg}^{-1}$. $\mathrm{min}^{-1}$. Both esterases hydrolyzed tributyrin, nitrophenyl esters up to a chain length of $\mathrm{C} 4$ and naphthylesters up to a chain length of C6. As for JL, it hydrolyzed short and long chain triacylglycerols and gave above $80 \%$ triacylglycerol conversion in transesterification reactions.

\section{Lupin Lipases (Lupinus luteus L.)}

Borek et al. (2006) observed the lipolytic activity of seed lipases from lupin (Lupinus luteus L.) cultivated in vitro in a medium with and without sugars. They observed increasing lipolytic activity up to a maximum of $96 \mathrm{~h}$ of incubation under both conditions. The authors also showed that seeds 
cultivated in a medium without sugar produced greater lipolytic activity than seeds cultivated in a medium with sugars. The lipids stored in the seed are for use as energy reserves and also for carbohydrate synthesis. Thus, seeds cultivated in a medium without sugars require lipids to obtain carbohydrates, which, in turn, require lipases to release the lipids.

Sanz and Olias (1990) studied the physicalchemical properties of lipases from non-germinated lupin seeds. The results showed that the lipase presented optimum activity at a $\mathrm{pH}$ of about 5.0 and temperature of $45^{\circ} \mathrm{C}$. The lipolytic activity increased in the presence of potassium $(10 \mathrm{mM})$, calcium $(1 \mathrm{mM})$ and magnesium $(1 \mathrm{mM})$ ions and the enzyme showed greater specificity for fatty acids at positions 1 and 2 of the lupin seed oil triacylglycerols, and was more active with saturated than unsaturated fatty acids.

\section{Linseed Lipases (Linum usitatissimum L.)}

Sammour (2005) studied linseed lipases (Linum usitatissimum L., "Giza 5") and the results showed that this was an acid lipase with an optimum $\mathrm{pH}$ of 4.5. This enzyme was particularly active between 36 and $84 \mathrm{~h}$ after seed germination and only showed low lipolytic activity in non-germinated grains. It was active with a large variety of triacylglycerols, especially C18:n, but was not active with mono and diacylglycerols. In specificity terms, the linseed lipase was similar to those of the canola and Barbados nut seeds.

\section{Coconut Lipases (Cocos nucifera linn)}

Ejedegba et al. (2007) studied the physicalchemical characteristics of semi-purified coconut lipases extracted with acetone. Four substrates were used to evaluate the enzymatic activity: triolein, tripalmitin, olive oil and coconut oil. The lipase showed a greater affinity for coconut oil, with an optimum $\mathrm{pH}$ of 8.5 and optimum temperature range of $35-40^{\circ} \mathrm{C}$ in triolein. The researchers also observed a greater affinity of this enzyme for long chain fatty acids at positions $s n-1$ and $s n-3$

\section{French Peanut Lipase (Panchira aquatica Bombacaceae)}

The recently discovered Panchira aquatica lipase was studied by the researchers Polizelli et al. (2008) with respect to the physical-chemical characteristics of the purified enzyme. The lipase showed maximum activity at $40^{\circ} \mathrm{C}$ and $\mathrm{pH} 8.0$ for an incubation period of $90 \mathrm{~min}$. Concerning temperature stability, in the range from 4 a $50^{\circ} \mathrm{C}$, it retained approximately $47 \%$ of its original activity for $3 \mathrm{~h}$. An increase in enzymatic activity was observed in the presence of $\mathrm{Ca}^{2+}$ and $\mathrm{Mg}^{2+}$ ions, and inhibition in the presence of $\mathrm{Hg}^{2+}, \mathrm{Mn}^{2+}, \mathrm{Zn}^{2+}$ and $\mathrm{Al}^{3+}$ ions. The enzyme was stable in the presence of organic solvents, and gave a $\mathrm{K}_{\mathrm{m}}$ of $1.63 \mathrm{mM}$ and $\mathrm{V}_{\max }$ of $37.3 \mu \mathrm{mol} \mathrm{mL} \mathrm{m}^{-1} \cdot \mathrm{min}^{-1}$ using $\rho$-nitrophenylacetate as the substrate. It showed an affinity for short chain fatty acids.

\section{Almond Lipase (Amygdalus communis L.)}

Almond seed lipases (Yesiloglu and Baskurt, 2008) presented optimum activity at a $\mathrm{pH}$ value of about 8.5. The enzyme, semi purified with ammonium sulfate, showed similar behavior to the other lipases with $\mathrm{K}_{\mathrm{m}}$ and $\mathrm{V}_{\max }$ values of, respectively, $25 \mathrm{mM}$ and $113.63 \mu \mathrm{mol} \cdot \mathrm{min}^{-1} \cdot \mathrm{mg}^{-1}$ using tributyrin as the substrate. It showed good hydrolysis activity with all the substrates studied (olive oil, corn, soybean, sunflower seed, almond, tributyrin and triolein). With respect to temperature, the lipase was stable between $20^{\circ} \mathrm{C}$ and $90^{\circ} \mathrm{C}$, and stood out for having an optimum activity at $65^{\circ} \mathrm{C}$ in soybean oil. Its activity in soybean oil was increased by the addition of $\mathrm{Ca}^{2+}, \mathrm{Fe}^{2+}, \mathrm{Mn}^{2+}, \mathrm{Co}^{2+}$ and $\mathrm{Ba}^{2+}$ salts, but was strongly inhibited by $\mathrm{Mg}^{2+}, \mathrm{Cu}^{2+}$ and $\mathrm{Ni}^{2+}$ salts. The enzyme retained its activity after six months storage at $-20^{\circ} \mathrm{C}$.

\section{Laurel Lipases (Laurus nobilis L.)}

The laurel (Laurus nobilis L.) is a tree of the genus Laurus, from the botanical family Lauraceae or Laurel, originally from the Mediterranean area. The laurel seed lipase was isolated and characterized by Isbilir et al. (2008), and the seed oil itself used to determine all the characteristics. The optimum $\mathrm{pH}$ value was 8.0 , but it was stable in the $\mathrm{pH}$ range from 7.0 to 10.0 . The optimum temperature was $50^{\circ} \mathrm{C}$, but it retained $68 \%$ of its activity after $1 \mathrm{~h}$ at $68^{\circ} \mathrm{C}$. Unlike most other lipases, this enzyme presented significantly higher activity not only with $\mathrm{Ca}^{2+}$ and $\mathrm{Mg}^{2+}$ ions, but also with $\mathrm{Co}^{2+}, \mathrm{Cu}^{2+}$ and $\mathrm{Fe}^{2+}$ ions.

\section{Black-Cumin Lipases (Nigella sativa)}

Dandik and Aksoy (1996) studied some applications of the seed lipase from black-cumin, a plant from Southeast Asia, with respect to its use in oleochemical reactions. The esterification of oleic acid with ethanol was evaluated without removal of the water from the medium. Greater ester production was observed at $45^{\circ} \mathrm{C}$ using a proportion of $1: 1.5$ 
methanol:oleic acid and 50\% of pressed seed in relation to the total weight of the reagents. The esterification of glycerol with oleic acid was also studied without removal of the water, using different substrate proportions. The highest conversion of oleic acid was obtained with a glycerol to oleic acid molar ratio of $4: 1$ at $45^{\circ} \mathrm{C}$, giving a product containing $31.2 \%$ of monolein, $37.3 \%$ of diolein, $15.7 \%$ of triolein and $15.8 \%$ of oleic acid.

Akova and Ustun (2000) evaluated the adsorption of the Nigella sativa lipase onto Celite at different $\mathrm{pH}$ values. They observed that adsorption increased from 14.4 to $24.3 \mathrm{mg} . \mathrm{g}^{-1}$ as the $\mathrm{pH}$ was reduced from 8.0 to 5.0 , and that $\mathrm{pH} 6$ was the optimum $\mathrm{pH}$ value for activity. Thus, the authors established a $\mathrm{pH}$ value of 6.0 as the best for adsorption, and, under this condition, the best for activity as well.

The Nigella sativa seed lipase was also studied by Tuter et al. (2003). The seed lipases were partially purified and then applied in transesterification and esterification reactions in the presence of different organic solvents. The experiments showed that the performance of the vegetable lipase was similar to that of microbial lipases, demonstrating its great potential for industrial applications.

\section{Cereal Seed Lipases}

Cereal grains contain from 2 to $10 \%$ of lipids, depending on the species and variety, and about 80 to $90 \%$ of the triacylglycerol fatty acids are oleic and linoleic (Hilditch and Williams, 1964). Lipids are normally located in the embryo (germ) and aleurone layer (the bran, which includes the pericarp, testa and part of the endosperm).

Lipolytic activity is present in different parts of cereal grains. Many researchers have focused their studies on these enzymes due to the process of rancidification that can occur during grain storage. The physiological function and exact location of these enzymes in the tissues are still important aspects to be discovered (Borgston and Borckman, 1984).

Some studies and the characteristics of cereal seed lipases such as rice, wheat, corn, oat, barley and sorghum are described and discussed below.

\section{Rice Lipases (Oryza sativa)}

Most of the lipolytic activity in rice is found in the bran (Borgston and Borckman, 1984). A heat stable lipase was identified in rice and purified by chromatography using Octyl-Sepharose. The enzyme is a glycoprotein with a molecular weight of $9.4 \mathrm{kDa}$ and has shown optimum activity at $80^{\circ} \mathrm{C}$ and $\mathrm{pH} 11.0$, using triolein as the substrate. The enzyme shows both phopholipase and hydrolysis activities, preferably at position $s n-2$ of phosphatidylcholine, although apparently it does not show positional specificity with triacylglycerols. Diisopropylfluorophosphate inhibited both the lipase and phospholipase activities (Bhardwaj et al., 2001).

\section{Wheat Lipases (Triticum aestivum L.)}

Wheat germ lipase, originally described by Singer and Hofstee (1948), is commercially available. Some authors have classified wheat lipase as an esterase, but Korneeva et al. (2008), Jing et al. (2003) and Kapranchikov et al. (2004) carried out their studies using triolein as the substrate, and showed good activity.

Rose and Pike (2006) determined the lipolytic activities of both wheat and wheat bran. Lipase activity in wheat bran ranged from 2.17 to 9.42 $\mathrm{U} / \mathrm{g}$, and in whole kernel wheat from 1.05 to 3.54 $\mathrm{U} / \mathrm{g}$. Optimal olive oil and water concentrations were 0.4 to $0.8 \mathrm{~mL}$ and 0.15 to $0.20 \mathrm{~mL}$ per $\mathrm{g}$ of defatted sample, respectively. Optimal incubation temperature was $40^{\circ} \mathrm{C}$, and incubation times of up to $8 \mathrm{~h}$ were linear. The authors observed that the lipolytic activity was highly related to the pool of free fatty acids in the stored wheat.

Purified wheat lipase $(143 \pm 2 \mathrm{kDa})$ showed optimum activity at alkaline $\mathrm{pH}$ values close to 8.0 and at $37^{\circ} \mathrm{C}$. The enzyme maintained $20 \%$ of its activity after incubation at temperatures from 60 to $90^{\circ} \mathrm{C}$ for an hour at $\mathrm{pH} 8.0$ (Kapranchikov et al., 2004). Similar results were reported by Jing et al. (2003) in their study using microemulsions with triolein as the substrate. They found a $\mathrm{K}_{\mathrm{m}}$ of $76 \pm 4$ $\mu \mathrm{mol} / \mathrm{L}$ and a $V_{\max }$ of $59 \pm 2 \mu \mathrm{mol} / \mathrm{mL} . \mathrm{h}$.

The active enzyme site was studied by Korneeva et al. (2008) using the Dixon method. The lipase was inactivated by diethylpyrocarbonate and dicyclohexylcarbodiimide, suggesting that the active enzyme site contained an aspartame, carboxylic or glutamic acid group and a histidine imidazole group. Other tests demonstrated that apparently the $\mathrm{OH}$ group of serine had an important function in the catalytic action of the enzyme.

\section{Corn Lipases (Zea mays L.)}

Lipolytic activity in corn grains was only observed two days after seed germination, and started to decrease along with the decrease in total stored lipids. The peak in lipolytic activity was about 
5-6 days after germination. This enzyme shows much greater activity with triolein than with mono and diolein. Huang et al. (1988) and Lin et al. (1986) observed that corn seed lipase showed higher activity with triacylglycerols that contained linoleic and oleic acids.

Liaquat and Apenten (2000) studied the synthesis of esters with different molecular weights by seed lipases precipitated with ammonium sulfate, in a medium containing organic solvents. Corn lipase showed better activity with short chain fatty acids in the following order: acetic $(2 \mathrm{C})>$ butyric $(4 \mathrm{C})>$ caproic acids $(6 \mathrm{C})$, in an organic medium using isopentanol and $72 \mathrm{~h}$ of reaction time.

Zhong et. al. (2007) studied recombinant dog lipase expressed in transgenic corn seed. Of the different surfactants evaluated, the enzyme showed greater stability in Tween 80 at a concentration of $0.01 \%(\mathrm{w} / \mathrm{w})$ and $\mathrm{pH} 5.5$. This study showed the possibility of genetically modifying the seeds, aiming at changing or increasing the lipolytic activity.

\section{Oat Lipases (Avena fatua)}

Oat lipase, partially purified by ion change chromatography, was studied by Mohamed et al. (2000). Four isoenzymes, EI, EII, EII and EIV, were separated by chromatography. The enzymes EII and EIII presented $\mathrm{K}_{\mathrm{m}}$ values of 0.52 and $0.38 \mathrm{mM}$, respectively; optimum activity at $\mathrm{pH} 9.0$ and half the maximum activity at $\mathrm{pH}$ values of $8.5,10$ and 10.5 ; and optimum activity at $75^{\circ} \mathrm{C}$ and $65^{\circ} \mathrm{C}$, respectively. The enzymes were heat stable, EII retaining $39 \%$ and EIII $23 \%$ of their activity at $90^{\circ} \mathrm{C}$. The enzymes were stimulated in the presence of $\mathrm{Ba}^{2+}$ and $\mathrm{Ca}^{2+}$ ions, but inhibited by $\mathrm{Mn}^{2+}$ and $\mathrm{Zn}^{2+}$ ions. Resistance to high temperatures and activity at alkaline $\mathrm{pH}$ values are important properties for possible industrial applications.

\section{Barley Lipases (Hordeum vulgare)}

Kubicka et al. (2000) identified lipase in germinated barley grains. The lipolytic activity was measured using glycerol tributyrate as substrate at $\mathrm{pH}$ 8.0. The authors found maximum activity two days after seed germination, followed by a decrease in activity, concomitantly with a decrease in stored lipids. Liaquat and Apenten (2000) evaluated the performance of barley lipase in ester hydrolyses in an organic medium containing (Z)-3-hexen-1-ol. They observed that the enzyme showed greater activity in the medium containing acetic acid (2C) as the substrate.

\section{Sesame Lipases (Sesamum indicum L.)}

The lipase of germinated sesame seed was studied by Wanasundara et al. (2001). The authors evaluated the lipolytic activity for 10 days after germination and found maximum activity four days after germination. The enzyme showed an affinity for short chain fatty acids at a temperature of $38^{\circ} \mathrm{C}$.

\section{Sorghum Lipase (Sorghum bicolor L.)}

Burukutu is an alcoholic drink produced with germinated sorghum seed, dried in the sun without removing the germ, ground and suspended in water for simultaneous saccharification and fermentation (Kun, 1997). Uvere and Orji (2002) evaluated the lipolytic activity during sorghum malting and fermentation (red and white varieties) for the production of Burukutu. The 5-day malt was fermented for $48 \mathrm{~h}$ to produce Burukutu, and the lipolytic activity was observed during this period. The $\mathrm{pH}$ of the fermentation medium decreased from 5.33 to 3.88 and from 5.35 to 3.85 , for the red and white seed malts, respectively. During fermentation, the red malt enzyme showed greater activity in a shorter time than the white malt enzyme.

Sorghum was also studied by some researchers as an alternative to barley malt replacement. Nwanguma et al. (1996) detected lipolytic activity in non-germinated sorghum seeds during grain malting and mashing. The authors observed a slight decrease in enzyme activity during steeping for 24 hours, but IT increased several fold in the course of germination. Between 24 and $60 \%$ of the lipolytic activity was retained after cooking at $48^{\circ} \mathrm{C}$, but no activity was found after mashing at $65^{\circ} \mathrm{C}$. About $68 \%$ of the lipase activity of $72 \mathrm{~h}$ old malt was detected in the plumule, while $29 \%$ and $3 \%$ were in the endosperm and radical, respectively.

No study was carried out to characterize the physical-chemical properties of the lipase present in sorghum grains; only the presence of lipolytic activity was determined. Since sorghum grains are being used to obtain products of great value, studies should be carried out to characterize the enzyme and its possible inhibitors in order to obtain products with better sensory quality.

A summary of the most widely studied seed lipases, their main physical and chemical features and their applications are shown in Table 3. 
Table 3: The most studied seed lipases and their main features and biochemical properties.

\begin{tabular}{|c|c|c|c|c|c|c|c|}
\hline Lipase Source & $\begin{array}{c}\text { Optimum } \\
\text { pH }\end{array}$ & $\begin{array}{c}\text { Optimum } \\
\text { Temperature } \\
\end{array}$ & Activator & Inhibitor & Substrate & $\begin{array}{c}\begin{array}{c}\text { Specificity } \\
\text { Position }\end{array} \\
\end{array}$ & Application \\
\hline $\begin{array}{l}\text { Africa bean seed } \\
\text { (Pentaclethra } \\
\text { macrophylla Benth) }\end{array}$ & 7.0 & $30^{\circ} \mathrm{C}$ & $\mathrm{Ca}^{2+}$ & EDTA & Coconut oil & - & Hydrolysis \\
\hline $\begin{array}{l}\text { French bean seed } \\
\text { (Phaseolus vulgaris) }\end{array}$ & 7.0 & $35^{\circ} \mathrm{C}$ & Tween-20 & $\mathrm{Ca}^{2+}$ & $\begin{array}{l}\text { Olive oil, } \\
\text { triacetin, oil } \\
\text { french bean } \\
\end{array}$ & - & Hydrolysis \\
\hline $\begin{array}{l}\text { Castor bean seed } \\
\text { (Phaseolus vulgaris) }\end{array}$ & 4.5 & $30^{\circ} \mathrm{C}$ & $\mathrm{Ca}^{2+}$ & $\begin{array}{l}\text { p-Chloromercuribenzoic } \\
\text { acid }\end{array}$ & $\begin{array}{l}\text { p-nitrophenyl } \\
\text { butyrate }\end{array}$ & $\begin{array}{l}s n-1 \\
s n-2 \\
\end{array}$ & Esterification \\
\hline $\begin{array}{l}\text { Rapeseed } \\
\text { (Brassica napus L.) }\end{array}$ & 7.0 & $37^{\circ} \mathrm{C}$ & $\begin{array}{l}\mathrm{Bi}^{3+} \\
\mathrm{Ca}^{2+}\end{array}$ & $\begin{array}{l}\mathrm{Fe} 3+, \mathrm{Fe} 2+, \mathrm{Zn} 2+ \\
\mathrm{Hg} 2+\text { and } \mathrm{Cu} 2+\end{array}$ & Olive oil & - & $\begin{array}{l}\text { Esterification } \\
\text { Transesterification }\end{array}$ \\
\hline $\begin{array}{l}\text { Barbados nut } \\
\text { (Jatropha curcas L.) }\end{array}$ & 7.5 & $37^{\circ} \mathrm{C}$ & $\begin{array}{l}\mathrm{Ca}^{2+} \\
\mathrm{Mg}^{2+}\end{array}$ & $\mathrm{Fe}^{2+}$ & Olive oil & - & Hydrolysis \\
\hline $\begin{array}{l}\text { Lupin seed } \\
\text { (Lupinus luteus L.) }\end{array}$ & 5.0 & $45^{\circ} \mathrm{C}$ & $\mathrm{Ca}^{2+}, \mathrm{Mg}^{2+}$ & - & Lupin oil & $\begin{array}{l}s n-1 \\
s n-2 \\
\end{array}$ & Hydrolysis \\
\hline $\begin{array}{l}\text { French peanut } \\
\text { (Panchira aquatica } \\
\text { Bombacaceae) }\end{array}$ & 8.0 & $40^{\circ} \mathrm{C}$ & $\begin{array}{l}\mathrm{Ca}^{2+} \\
\mathrm{Mg}^{2+}\end{array}$ & $\begin{array}{l}\mathrm{Hg}^{2+}, \mathrm{Mn}^{2+}, \mathrm{Zn}^{2+} \\
\text { and } \mathrm{Al}^{3+}\end{array}$ & $\begin{array}{l}p \text {-nitrophenyl } \\
\text { acetate }\end{array}$ & - & Hydrolysis \\
\hline $\begin{array}{l}\text { Almond seed } \\
\text { (Amygdalus } \\
\text { communis L.) } \\
\end{array}$ & 8.5 & $65^{\circ} \mathrm{C}$ & $\begin{array}{l}\mathrm{Ca}^{2+}, \mathrm{Fe}^{2+}, \mathrm{Mn}^{2+}, \\
\mathrm{Co}^{2+} \text { and } \mathrm{Ba}^{2+}\end{array}$ & $\mathrm{Mg}^{2+}, \mathrm{Cu}^{2+}$ and $\mathrm{Ni}^{2+}$ & Soybean oil & - & Hydrolysis \\
\hline $\begin{array}{l}\text { Laurel seed } \\
\text { (Laurus nobilis L.) }\end{array}$ & 8.0 & $50^{\circ} \mathrm{C}$ & $\begin{array}{l}\mathrm{Ca}^{2+}, \mathrm{Mg}^{2+}, \mathrm{Co}^{2+}, \\
\mathrm{Cu}^{2+} \text { and } \mathrm{Fe}^{2+}\end{array}$ & - & Laurel oil & - & Hydrolysis \\
\hline $\begin{array}{l}\text { Black-Cumin seed } \\
\text { (Nigella sativa) }\end{array}$ & 6.0 & $45^{\circ} \mathrm{C}$ & - & - & Olive oil & - & $\begin{array}{l}\text { Hydrolysis, } \\
\text { Esterification } \\
\text { Transesterification }\end{array}$ \\
\hline $\begin{array}{l}\text { Rice seed } \\
(\text { Oryza sativa })\end{array}$ & 11.0 & $80^{\circ} \mathrm{C}$ & - & - & Olive oil & $s n-2$ & Hydrolysis \\
\hline $\begin{array}{l}\text { Wheat seed } \\
\text { (Triticum aestivum } \text { L.) }^{*}\end{array}$ & 8.0 & $37^{\circ} \mathrm{C}$ & - & - & Triolein & - & $\begin{array}{l}\text { Hydrolysis, } \\
\text { Esterification }\end{array}$ \\
\hline $\begin{array}{l}\text { Oat seed } \\
\text { (Avena fatua) }\end{array}$ & 9.0 & $65-75^{\circ} \mathrm{C}$ & $\begin{array}{l}\mathrm{Ba}^{2+} \\
\mathrm{Ca}^{2+}\end{array}$ & $\mathrm{Mn}^{2+}$ and $\mathrm{Zn}^{2+}$ & $\begin{array}{l}\text { p-nitrophenyl } \\
\text { palmitate }\end{array}$ & - & Hydrolysis \\
\hline $\begin{array}{l}\text { Coconut seed } \\
(\text { Cocos nucifera } \text { linn })\end{array}$ & 8.5 & $30-40^{\circ} \mathrm{C}$ & - & - & Olive oil & $\begin{array}{l}s n-1 \\
s n-3\end{array}$ & Hydrolysis \\
\hline
\end{tabular}

${ }^{*}$ Commercial Lipase

\section{Lipase Applications}

The versatility of lipases in catalyzing different kinds of reactions associated with their different specificities endows these enzymes with an important and vast application potential (Gandhi, 1997; Sharma et al., 2001; Pastore et al., 2003; Enujiugha et al., 2004; Hansan et al., 2006; Parques et al., 2006; Freire and Castilho, 2008; Yesiloglu and Baskurt, 2008; Isibilar et al., 2008; Polizelli et al., 2008). Lipases are excellent alternatives for classic chemical syntheses with industrial applications, such as in foods, detergents, oleochemicals, pharmaceuticals, fine chemistry, cosmetics and fragrances, paper pulp, leather, biosensors and lipidrich wastewater treatment (Gandhi, 1997; Paques et al., 2006; Freire and Castilho, 2008).

\section{Food}

Lipases are employed in food manufacturing to liberate fatty acids into food products by selective hydrolysis of the fats and oils present in many kinds of food. Depending on the carbon chain length and on the degree of unsaturation, the fatty acid obtained provides the food with flavors, colors and unusual smells, playing an important role in the physicalchemical, organoleptic and nutritional properties of many products (Gandhi, 1997; Sharma et al., 2001; Freire and Castilho, 2008).

Wheat, barley, corn and canola seed lipases were used to produce low molecular weight esters in an organic environment (Liaquat and Apent, 2000). The authors observed that the crude lipase extracts from each of these seeds were efficient for the synthesis of esters. Germinated canola seed lipase showed better performance with respect to the synthesis of esters when compared with the other enzymes analyzed. ( $Z$ )-hexen-1-yl butyrate and ( $Z$ )3 -hexen-1-yl caproate were obtained in about $96 \%$ yield, and butyl butyrate, isopentyl butyrate, butylcaproate and isopentyl caproate in $80 \%$ yield. Canola seed lipases presented about a $63 \%$ yield for ethyl acetate and butyl acetate, whereas barley and corn seed lipases only presented $40 \%$ yield. Thus, the crude, semi-purified canola extract is an excellent alternative for the production of esters in an organic environment. 


\section{Detergents}

The use of lipases as functional compounds in the formulation of detergents is responsible for the sale of about 1,000 tons of lipases every year, or about $32 \%$ of the total lipase sales (Sharma et al., 2001). The main features necessary are stability under the conditions of washing ( $\mathrm{pH}$ between 10.0 and 11.0 and temperatures between $30^{\circ} \mathrm{C}$ and $60^{\circ} \mathrm{C}$ ), resistance to the other components of the formulation (such as alkyl-bezenesulphonates and proteases) and low substrate specificity, i.e., an ability to hydrolyze fats with various compositions.

Rice (Oryza sativa) and oat (Avena fatua) seed lipases present suitable features for their use in detergents (Table 3). They are stable at alkaline $\mathrm{pH}$ values and at temperatures of about $60^{\circ} \mathrm{C}$.

\section{Oils and Fats}

Lipases show a wide range of applications in oil chemical industries. Their usage reduces expenses with energy and minimizes the heat degradation of compounds in comparison to traditional chemical processes (Freire and Castilho, 2008).

Tuter et al. (2003) used Nigella sativia L. seed lipases to enrich borage oil with gamma-linolenic acid. The best result was obtained in an experiment carried out with $330 \mathrm{U} / \mathrm{g}$ of semi-purified freezedried seed extract and $200 \mathrm{U} / \mathrm{g}$ of freeze-dried seed and oil.

Tuter et al. (1998) used castor bean lipase as the biocatalyst in the esterification of fatty acids and glycerol. The enzyme showed optimal efficiency in the formation of new tri-, di- and monoglycerols, presenting great potential for the production of triacylglycerols of interest.

\section{Fine Chemistry}

The pharmaceutical and fine chemical industries have long used lipases in their productive processes. Lipase regio-, enantio-, and chemoselectivity features allow their use for the resolution of racemic mixtures and the removal of some compounds. In general, these enzymes show excellent stability in the presence of organic solvents, in which the substrates are soluble (Jaeger and Eggert, 2002; Gotor-Fernádez et al., 2006).

Xia et al. (2009) used wheat germ lipase for the kinetic resolution of secondary alcohols. The following alcohols were used: $(R . S)$-1-phenylethanol (rac-1a), (R.S)-2-chloro-1-phenylethanol (rac-1b), (R.S)-1-(3-clorophenyl) ethanol (rac-1c), (R.S)-1-(4clorophenyl) ethanol (rac-1d), (R.S)-2-octanol (rac- 1e), (R.S)-2-butanol (rac-1f) and (R.S)-1-(4methoxyphenyl) ethanol (rac-1g). The wheat lipase showed high kinetic resolution for aryl sec-alcohol and a relatively low conversion ratio with aliphatic alcohols such as 2-octanol and 2-butanol. Furthermore the wheat lipase showed high enantioselectivity for aryl sec-alcohol, especially for 1-phenylethanol, as compared to 2-octanol and 2butanol. The authors reported the possibility of using wheat lipase in chiral syntheses, combined with other lipases.

\section{Biodiesel}

The use of lipase in biodiesel production has shown promising results in recent years. Using the enzymatic route, the by-product glycerol can easily be removed without the requirement of a complex separation process. In addition, oil-free fatty acids, which can be used as the raw material, are also completely converted into alkyl esters (Fukuda et al., 2001).

The choice of the best enzyme sources and optimization of the medium conditions, such as the substrate and solvent concentrations (Park e Mori, 2008) or the absence of solvents (Du et al., 2006), the temperature, water content, free fatty acid level, acyl migration and viscosity of the reaction medium in the bioreactor determine the success of the process.

Donato et al. (2008) suggested the production of methyl and ethyl esters using several esterification processes after the hydrolysis of different oils by vegetable lipases. According to these researchers, fatty acids can be obtained from the hydrolysis of palm oil by crushed castor beans; the hydrolysis of palm oil by an acetone extract from castor beans; the hydrolysis of pine seed oil by crushed castor beans and the hydrolysis of palm oil by the lipases present in the fruit itself. Every vegetable extract presents lipolytic activity, which can be applied in the production of fatty acids from the triacylglycerols obtained from a variety of sources, considering that the fatty material can be esterified by methanol or ethanol for biodiesel production.

Research in this field is still in progress due to the flexibility of the enzymes and the high cost of commercialization (Guan et al., 2009). The main studies focus on the relationship between the enzymatic production of biodiesel and the productivity of the biofuel manufacturing process (Nielsen et al., 2008).

Table 4 presents a summary of the applications and yields of the seed lipases mentioned above. 
Table 4: Some seed lipases and their applications

\begin{tabular}{|l|l|l|l|}
\hline \multicolumn{1}{|c|}{ Lipase Source } & \multicolumn{1}{|c|}{ Application } & \multicolumn{1}{|c|}{$\begin{array}{c}\text { Yield } \\
\text { (\%) }\end{array}$} & \multicolumn{1}{|c|}{ Authors } \\
\hline Barley seed (Hordeum vulgare L.) & Production of low molecular weight esters & 40 & Liaquat and Apent, 2000 \\
Maize seed (Zea mays L.) & Production of low molecular weight esters & 40 & Liaquat and Apent, 2000 \\
Linseed (Linum usitatissimum) & Production of low molecular weight esters & 63 & Liaquat and Apent, 2000 \\
Rapeseed (Brassica napus L.) & Production of low molecular weight esters & 96 & Liaquat and Apent, 2000 \\
Black-Cumin seed (Nigella sativia L) & Synthesis of structured lipids & 31 & Tuter et al. (2003) \\
Castor bean seed (Phaseolus vulgaris) & Synthesis of structured lipids & 53 & Tuter et al. (1998) \\
Wheat germ seed (Triticum sp) & Esterification & 99 & Xia et al. (2009) \\
Vernonia seed (Vernonia galamensis) & Hydrolysis of oils & 80 & Ncube and Read (1995) \\
Rapeseed (Brassica napus L.) & Esterification & 98 & Jchmanián and Mukhrjee (1996) \\
Black-Cumin seed (Nigella sativia L) & Synthesis of structured lipids & 81 & Dandik and Aksoy (1996) \\
\hline
\end{tabular}

\section{CONCLUSIONS AND PERSPECTIVES}

Lipases are currently important as biocatalysts. A great number of articles have been published, especially concerning synthesis reactions, emphasizing the importance of lipases. The search for new lipases must be continuous and interesting seed sources must be well explored, since they may present different biochemical properties with respect to the reactions of hydrolysis and synthesis. There are a huge number of new seed sources for possible lipase exploitation. In the authors' laboratory, lipases from Jatropha curcas, castor bean, sorghum seed and soybean have been exploited for different reactions, achieving very promising results. Seed lipase sources can represent a cheaper and faster way to produce these important biocatalysts.

\section{REFERENCES}

Abigor, R. D., Uadia, P. O., Foglia, T. A., Haas, M. J., Scott, K. and Savary, B. J., Partial Purification and Properties of Lipase From Germinating Seeds of Jatropha curcas. L. Journal of the American Oil chemist's Society, 79, No. 11, 1123 (2002).

Akova, A. and Ustung, G., Activity and Adsorption of Lipase from Nigella sativa Seeds on Celite at Different $\mathrm{pH}$ values. Biotechnology Letters, 22, No. 5, 355 (2000).

Alonso, F. O. M., Oliveria, E. B. L., Dellamora-Ortiz, G. M. and Pereira-Meirelles, F. V., Improvement of Lipase Production at Different Stirring Speeds and Oxygen Levels. Brazilian Journal of Chemical Engineering, 22, No. 1, 9 (2005).

Bhardwaj, K., Raju, A. and Rajasekharan, R., Identification, Purification, and Characterization of a Thermally Stable Lipase from Rice Bran: A new member of the (Phospho) lipase family. Plant Physiology, 127, No. 4, 1728 (2001).
Borek, S., Ratajczak, W., Ratajczak, L., Ultrastructural and Enzymatic Research on the Role of Sucrose in Mobilization Storage Lipids in Germinating Yellow Lupine Seeds. Plant Science, 170, No. 3, 441 (2006).

Borgston, B. and Brockman, H. L., Lipases. Amsterdam, Elsevier (1984).

Caro, Y., Villeneuve, P., Pina, M., Reynes, M. and Graille, J., Lipase Activity and Fatty acid Typoselectivities of Plant Extracts in Hydrolysis and Interesterification. Journal of the American Oil Chemists' Society, 77, No. 4, 350 (2000).

Castro, H. F., Oliveira, P. C. and Pereira, E. B., Influence of Substrate Partition Coefficient on the Performance of Lipase Catalyzed Synthesis of Citronellyl Acetate by Alcoholysis. Brazilian Journal of Chemical Engineering, 17, No. 4-7, 1 (2000).

Dandik, L. and Aksoy, A., Applications of Nigella sativa Seed Lipase in Oleochemical Reactions. Enzyme and Microbial Technology, 19, No. 4, 277 (1996).

De Castro, H. F., Mendes, A. A. Santos, J. C. and Lima, C. A., Modificação de Óleos e Gorduras por Biotransformação. Química Nova, 27, No. 1, 146 (2004).

Du, D., Sato, M., Mori, M. and Park, E. Y., Repeated Production of Fatty Acid Methyl Ester With Activated Bleaching Earth in Solvent-free System. Process Biochemistry. 41, No. 8, 1849 (2006).

Donato, A. G. A., Antunes, O. A. C., Freire, D. M. G., Lago, R. C. A., Cavalcanti, E. D. C. and Sousa, J. S., Produção de Ácidos Graxos Catalisada por Lipases não Purificadas de Sementes ou Frutos Vegetais para Subseqüente Esterificação por Catálise Ácida. PI 0603824-7 A (2008).

Eastmond, P. J., Cloning and Characterization of the Acid lipase From Castor Beans. The Journal of Biological Chemistry, 279, No. 44, 45540 (2004).

Ejedegba, B. O., Onyeneke, E. C. and Oviasogie, P. O., Characteristics of Lipase Isolated from 
Coconut (Cocos nucifera linn) Seed Under Different Nutrient Treatments. African Journal of Biotechnology, 6, No. 6, 723 (2007).

Enujiugha, V. N., Thani, F. A., Sanni, T. M. and Abigor, R. D., Lipase Activity in Dormant Seeds of the African oil bean (Pentaclethra macrophylla Benth), Food Chemistry, 88, No. 3, 405 (2004).

Freire, G. D. M. and Castilho, F. L., Lipases em Biocatálise. In: Bon et al. (org). Enzimas em biotecnologia: Produção, Aplicação e Mercado. Rio de Janeiro, Interciência (2008).

Fukuda, H., Kondo, A. and Nodo, H., Biodiesel Fuel Production by Transesterification oil, Journal of Bioscience and Bioengineering, 92, No. 5, 405 (2001).

Gandhi, N. G., Application of Lipase. Journal of the American Oil Chemists' Society, 74, No. 6, 621 (1997).

Guan, G., Sakurai, N., and Kusakabe, K., Synthesis of Biodiesel from Sunflower Oil at Room Temperature in the Presence of Various Cosolvents. Chemical Engineering Journal, 146, No. 2, 302 (2009).

Gotor-Fernández, V., Brieva, R. and Gotor, V., Lipases: Useful Biocatalysts for the Preparation of Pharmaceuticals. Journal of Molecular Catalysis B: Enzymatic, 40, No. 3-4, 111 (2006).

Hammer, M. F. and Murphy, J. B., Lipase Activity and in vivo Triacylglycerol Utilization. Annual Review of Ecology and Systematics, 24, No. 3, 69 (1993).

Hasan, F., Shah, A. A. and Hameed, A., Industrial Applications of Microbial Lipases. Enzyme Microbial and Technology, 39, No. 2, 235 (2006).

Hassaniem, F. R. and Mukhrjee, K. D., Isolation of Lipase from Germinating Oilseeds for Biotechnological Processes. Journal of the American Oil Chemists' Society, 63, No. 7, 893 (1986).

Hellyer, S. A., Chandler, I. C. and Bosley, J. A., Can the Fatty Acid Selectivity of Plant Lipases be Predicted from the Composition of the Seed Triglyceride? Biochemica et Biophysica Acta, 1440, No. 2-3, 215 (1999).

Hilditch, T. P. and Willians, P. N., The Chemical Constitution of Natural Fats. Chapman and Hall, London (1964).

Huang, A. H. C., Lin, Y. H., Wang, S. M., Characteristics and Biosynthesis of Seed Lipases in Maize and Other Plant Species. Journal of the American Oil Chemists' Society, 65, No. 6, 897 (1988).

Huang, A. C. and Moreau, R. A., Lipases in the Storage Tissues of Peanut and Other Oil Seeds
During Germination. Planta, 141, No. 1, 111 (1978).

Isbilir, S. S., Ozcan, M. H. and Yagar, H., Some Biochemical Properties of Lipase from Bay Laurel (Laurus nobilis L.) Seeds. Journal of the American Oil Chemists' Society, 85, No. 3, 227 (2008).

Jachmanián, I. and Mukherjee, K. D., Esterification and Interesterification Reactions Catalyzed by Acetone Power from Geminating Rapeseed. Journal of the American Oil Chemists' Society, 73, No. 11, (1996).

Jaeger, K. E. and Eggert, T., Lipases for Biotechnology. Current Opinion in Biotechnology, 13, No. 4, 390 (2002).

Jing, F., An X. and Shen, W., The characteristics of Hydrolysis of Triolein Catalyzed by Wheat Germ Lipase in Water-in-oil Microemulsions. Journal of Molecular Catalysis B: Enzymatic, 24-25, No. 3, 43 (2003).

Kapranchikov, V. S., Zherebtsov, N. A. and Papova, T. N., Purification and Characterization of Lipase from Wheat (Triticum aestivum L.) germ. Applied Biochemistry and Microbiology, 40, No. 1, 84 (2004).

Kermasha, S. and Van de Voort, F. R., Characterization of French Bean (Phaseolus vulgaris) seed lipase. Canidan Intitute of Food Science and Technology, 19, No. 1, 23 (1986).

Kamimura, E. S., Mendieta, O., Sato, H. H., Pastore G. and Maugeri, F., Production of Lipase from Geotrichum sp and Adsorption Studies on Affinity Resin. Brazilian Journal of Chemical Engineering, 16, No. 2, 103 (1999).

Korneeva, O. S., Popova, T. N., Kaprochikov, V. S. and Montina, E. A., Identification of Catalytically Active Groups of Wheat (Triticum aestivum) Germ Lipase. Applied Biochemistry and Microbiology, 44, No. 4, 349 (2008).

Kubicka, E., Grabska, J., Jedrychowski, L. and Czyz, B., Changes of Specific Activity of Lipase and Lipoxygenase During Germination of Wheat and Barley. International Journal of Food Science and Nutrition, 51, No. 4, 301 (2000).

Kun, O. S. M., Chemical Changes a Nutritive Values of Burukutu (a Nigeria beverage). Nahrung, 41, No. 6, 375 (1997).

Leal, M. C. M., Cammarota, M. C., Freire, D. M. G. and Sant'Anna, Jr., G. L., Hydrolytic Enzymes as Coadjuvants in the Anaerobic Treatment of Dairy Wastewaters. Brazilian Journal of Chemical Engineering, 19, No. 2, 175 (2002).

Liaquat, M. and Apenten, R. K. O., Synthesis of Low Molecular Weight Flavor Esters Using Plant 
Seedling Lipases in Organic Media. Journal of Food Science: Food Chemistry and Toxicology, 65, No. 2, 295 (2000).

Lin, Y. H., Yu, C. and Huang, A. H., Substrate Specificities of Lipase from Corn and Other Seeds. Archives of Biochemistry and Biophysics, 244, No. 1, 346 (1986).

Macrae, A. R. and Hammond, R. C., Present and Future Applications of Lipases. Biotechnology Genetics and Engineering Review, 3, 193 (1985).

Merçon, F., Erbes, V. L., Sant'Anna, Jr. G. L. and Nobrega, R., Lipase Immobilized Reactor Applied to Babassu Oil Hydrolysis, Brazilian Journal of Chemical Engineering, 14, No. 1, (1997).

Mohamed, M., Mohamed, T. M., Mohamed, S. A. and Fahmy, A. S., Distribution of Lipases in the Gramineae. Partial Purification and Characterization of Esterase from Avena fatua. Bioresource Technology, 73, No. 3, 227 (2000).

Ncube, I. and Read, J. S., Evaluation of Vernonia galamensis (acetone power) for Use in Biotechnology. Industrial Crops and Products, 3, No. 4, 285 (1995).

Nielsen, P. M., Brask, J. and Fjerbaek, L., Enzymatic Biodiesel Production: Technical and Economical Considerations. European Journal Science Technology, 110, No. 8, 692 (2008).

Noor, I. M., Hasan, M. and Ramachandran, K. B., Effect of Operating Variables on the Hydrolysis Rate of Palm Oil by Lipase. Process Biochemistry, 39, No. 13 (2003).

Nwanguma, B. C., Eze, M. O. and Ezengwa, O. O., Changes in Activity of Sorghum Lipase Malting and Mashing. Journal of Institute of Brewing, 102, No. 1, 39 (1996).

Paques, F. W. and Macedo, G. A., Lipases de Látex Vegetais: Propriedades e Aplicações Industriais: A Review. Química Nova, 29, No. 1, 93 (2006).

Pastore, M. G., Costa, V. S. and Koblitz, M. G. B., Purificação Parcial e Caracterização Bioquímica de Lipase Extracelular Produzida por Nova Linhagem de Rhizopus sp. Ciência e Tecnologia de Alimentos, 23, No. 2, 135 (2003).

Park, E. Y. and Mori, M., Kinetic Study of Esterification of Rapessed Oil Contained in Waste Activated Bleaching Earth Using Candida rugosa Lipase in Organic Solvent System. Journal of Molecular Catalysis B: Enzymatic, 37, No. 1-6, 95 (2008).

Pereira, E. P., Zanin, G. M. and Castro, H. F., Immobilization and Catalytic Properties of Lipase on Chitosan for Hydrolysis and Esterefication Reactions. Brazilian Journal of Chemical Engineering, 20, No. 4, 343 (2003).
Polizelli, P. P. Tiera, M. J. and Bonilla-Rodriguez, G. O., Effect of Surfactants and Polyethylene Glycol on the Activity and Stability of a Lipase from Oilseeds of Pachiraaquatica. Journal of the American Oil Chemists' Society, 85, No. 8, 749 (2008).

Quettier, A. L. and Eastmond, P. J., Storage Oil Hydrolysis During Early Seedling Growth. Plant Physiology and Biochemistry, 47, 485 (2009).

Quettier, A. L., Shaw, E. and Eastmond, P. J., Sugardependents Encodes a Mitochondrial FADdependent Glyceol-3-phosphate Dehydrogenase, Which is Required for Glycerol Catabolism and Post-germinative Seedling Growth in Arabidopsis. Plant Physiology, 148, No. 1, 519 (2008).

Rakhimov, M. M., Dzhanbaeva, N. R. and Yuldashev, P. K., Specificity the Lipase of Cottonseed. Chemical of the Natural Compounds, 6, No. 5, 616 (1970).

Ribeiro, A. P. B., Basso, R. C., Grimaldi, R. Gioielli, L. A., Santos, A. O. dos Cardoso, L. P. and Gonçalves, L. A. G., Influence of Chemical Interesterification on Thermal Behavior, Microstructure, Polymorphism and Crystallization Properties of Canola Oil and Fully Hydrogenate Cottonseed Oil Blends. Food Research International, 42, 1153 (2009).

Rose, D. J. and Pike, O. A., A Simple Method to Measure Lipase Activity in Wheat and Wheat Bran as an Estimation of Storage Quality. Journal of the American Oil Chemist's Society, 83, No. 5, 415 (2006).

Sadeghipour, H. R. and Bhatla, S. C., Light-enhanced Oil Body Mobilization in Sunflower Seedlings Accompanies Faster Protease Action on Oleosins. Plant Physiology and Biochemistry, 41, No. 4, 309 (2003).

Sagiroglu, A. and Arabaci, N., Purification and Characterization of Lipase from Sunflower Seed. Preparative Biochemistry and Biotechnology, 35, No. 1, 37 (2005).

Sammaour, R. H., Purification and Partial Characterization of an Acid Lipase in Germinating Lipidbody Linseedlings. Turkish Journal of Botany, 29, No. 3, 177(2005).

Sana, N. K., Hossin, I., Haque, E. M. and Shaha, R. K., Identification, Purification and Characterization of Lipase from Germinating Oil Seeds (Brassica napus L.). Pakistan Journal of Biological Sciences, 7, No. 2, 246 (2004).

Sanz, L. C. and Olias, J. M., Characterization of Lupin Seed Lipase. Food Chemistry, 37, No. 3, 221 (1990).

Sharma, R, Chisti, Y., Banerjee, U. C., Production, Purification, Characterization, and Applications 
of Lipases. Biotechnology Advances, 19, No. 8, 627 (2001).

Singer, T. P. and Hofstee, B. H. J., Studies on Wheat Germ Lipase. In: Methods of Estimation, Purification, and General Properties of the Enzyme. Archives of Biochemistry, 18, No. 2, 229 (1948).

Staubmann, R., Ncube, I., Gübitz, G. M., Steiner, W. and Read, J. S., Esterase and Lipase Activity in Jatropha curcas L. seeds. Journal of Biotechnology, 75, 117 (1999).

Sonnet, P. E., Lipase Selectivities. Journal of the American Oil Chemists' Society, 65, No. 6, 900 (1988).

Tuter, M., Secundo, F., Riva, S., Aksoy, H. A. and Ustun, G., Partial Purification of Nigella sativa L. Seed Lipase and Its Application in Transesterification Reactions. Journal of American Oils Chemists' Society, 80, No. 1, 43 (2003).

Tüter, M., Castor Bean Lipase as a Biocatalyst in the Esterification of Fatty Acids to Glycerol. Journal of the American Oil Chemist's Society, 75, No. 3, 417 (1998).

Uvere, P. O. and Orji, G. S., Lipase Activities During Malting and Fermentation of Sorghum for Burukutu Production. Journal of the Institute of
Brewing, 108, No. 2, 256 (2002).

Villeneuve, P., Plant Lipases and Their Applications in Oils and Fats Modification. European Journal of Lipid Science and Technology, 105, No. 6, 308 (2003).

Xia, X., Wang, Y. H., Yang, B. and Wang, X., Wheat Germ Lipase Catalyzed Kinetic Resolution of Secondary Alcohols in Non-aqueous Media. Biotechnology Letter, 31, 83 (2009).

$\mathrm{Xu}, \mathrm{X}$., Production of Specific-Structured Triacylglycerols by Lipase-Catalyzed Reactions: a Review. European Journal of Lipid Science and Technology, 3, 287 (2000).

Zhong, Q., Xu, L., Zhang, C. and Glatz, C. E., Purification of Recombinant Aprotinin from Transgenic Corn Germ Fraction Using Ion Exchange and Hydrophobic Interaction Chromatography. Applied Microbiology and Biotechnology, 76, No. 3, 607 (2007).

Yesiloglu, Y. and Baskurt, L., Partial Purification and Characterization of Almond Seed Lipase. Preparative Biochemistry \& Biotechnology, 38, No. 4, 397 (2008).

Wanasundara, P. K. P. D., Wansudara, U. N. and Shahidi, F., Lipolitic Activity of Enzymes form Germinating Seeds of Sesame (Sesamum indicum L.). Journal of Food Lipids, 8, 75 (2001). 